\title{
SAVING PLANTS FROM DISEASE
}

\author{
TO PREVENT OUTBREAKS OF DISEASE DESTROYING WHEAT AND OTHER \\ VITAL FOOD CROPS, SCIENTISTS FROM THE ROTHAMSTED RESEARCH \\ AND EUROPEAN BIOINFORMATICS INSTITUTES ARE SHARING GENETIC \\ AND GENOMIC INFORMATION ON DISEASE-CAUSING MICROORGANISMS
}

\section{WHAT'S THE PROBLEM?}

Every year, up to one-quarter of plants grown for food are spoiled or killed outright by disease before the crop can be harvested. Those that survive are sometimes later destroyed by disease while being transported around the world. It's hard to predict where in the world new outbreaks will happen. As the world warms up due to climate change, the microorganisms (fungi, protists, bacteria and viruses) that cause diseases are gradually moving towards Earth's poles. They can also be carried to new locations by severe storms, and inadvertently by humans, animals, or traded goods. So, what can be done to solve this problem?

\section{UP TO $1 / 4$}
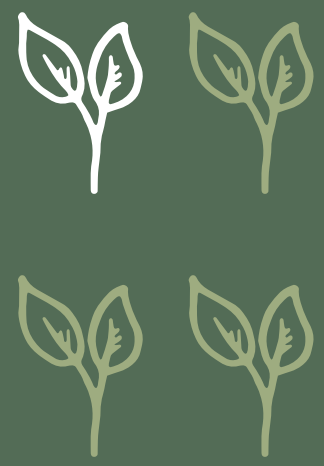

OF PLANTS GROWN FOR FOOD ARE SPOILED OR KILLED OUTRIGHT BY DISEASE
To prevent plant diseases, scientists at the Rothamsted Research and European Bioinformatics Institutes are sharing detailed genetic and genomic information about 'pathogenic organisms' contained in two databases: PHI-base and PhytoPath.

\section{WHAT ARE THE PATHOGEN-HOST \\ INTERACTIONS DATABASE \\ (PHI-BASE) AND PHYTOPATH?}

$\mathrm{PHI}$-base and PhytoPath are databases that help researchers discover more about organisms that cause disease (plant pathogens). Scientists use these databases to look up information on a pathogen to find out which genes and gene clusters are responsible for infecting a plant (the host). This improved knowledge is important for devising ways to prevent diseases from occurring in the first place, or to reduce the spread of disease because a disease may go on to infect either more plants of the same species, or other plant species.

Genes provide the instructions that tell plants, animals and humans how to make proteins, including enzymes and chemical messengers. In humans, for example, a variety of genes determine the colour of your eyes or hair, and we inherit different genes from each of our parents depending on the genetic segregation battles that take place in specific cells. All of the genes in a given organism make up its genome (its DNA blueprint), and it's the DNA sequence of genes that govern the proteins, enzymes and chemical messengers that are produced. The genes known to cause pathogenic diseases are included in $\mathrm{PHI}$-base. These can be accessed from PhytoPath, as well as whole genome sequences that it pulls in from another database called Ensembl.
$\mathrm{PHI}$-base is updated regularly, with the latest version including data on 6,438 genes from 263 pathogens and 194 hosts. It provides detailed information on the genes that affect the outcome of interactions between pathogens and hosts. It also gives information on 'host target sites', which detect the presence of a pathogen and activate the plant's defences.

WHAT KIND OF ORGANISMS CAUSE PLANT DISEASES?

PHI-base and PhytoPath include data on three types of plant pathogen: fungi, bacteria, and single-celled organisms called protists. For example, a fungus that causes stem rust is called Puccinia graminis; a bacterium that stops rice seeds from growing is called Burkholderia glumae; and a protist that causes potato blight is called Phytophthora infestans.

Too small to be seen with the naked eye, protists are sometimes called water moulds. That's because many species can swim in water, thanks to a microscopic whip-like appendage called a flagellum. Many protists are dispersed and infect plants only when it rains. As well as infecting plants, protists are also responsible for major diseases in humans and animals, including malaria.

Strange as it may seem, not all diseases caused by pathogens are undesirable. The Botrytis cinerea fungus causes grey mould disease on a large number of fruit and vegetable species, which is definitely unwanted. But it is also responsible for 'noble rot', which wine producers love. Grapes that pick up this infection at the right time produce fine, concentrated sweet wine. 


\section{FIVE DEADLY PLANT PATHOGENS}

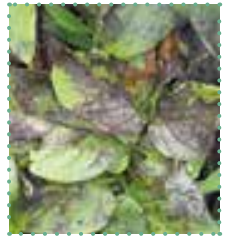

PHYTOPHTHORA INFESTANS: This protist caused the world's most deadly potato disease. Between 1845 and 1851, it was responsible for the Irish Potato Famine, which led to the deaths of $21 \%$ of the Irish population. This is still the number one potato disease, globally.
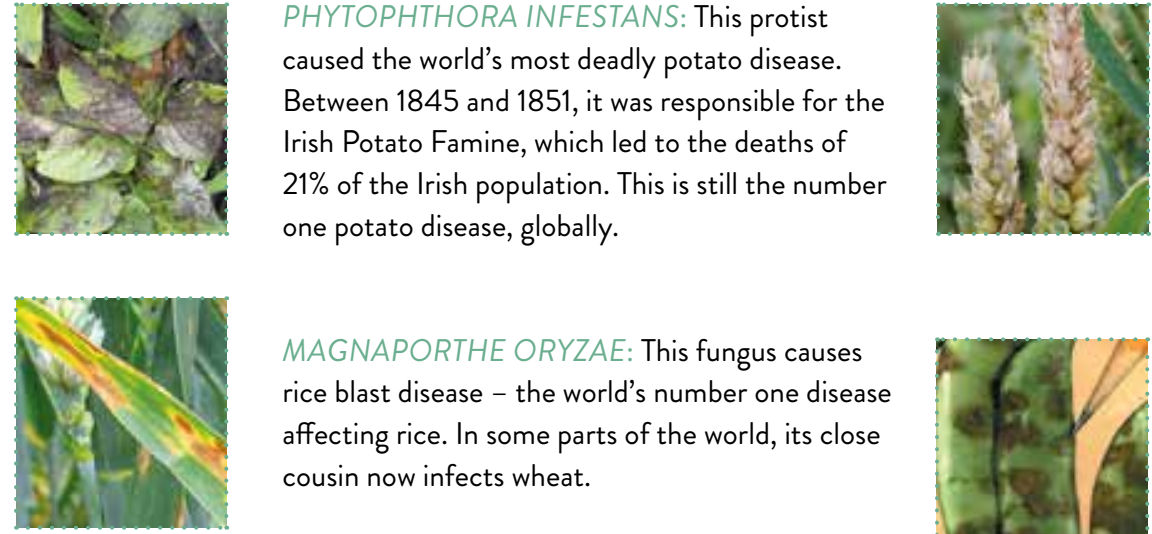

MAGNAPORTHE ORYZAE: This fungus causes rice blast disease - the world's number one disease affecting rice. In some parts of the world, its close cousin now infects wheat.

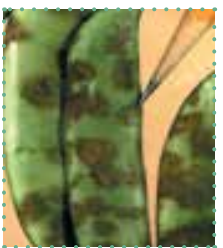

FUSARIA FUNGAL FAMILY: The species in this family affect cereal crops as well as bananas, tomatoes and vegetables. They can also cause illness in humans, including eye disease and, in some people, diseases of the lungs and blood. These fungi are also able to live in the soil and on decaying plant tissue once a crop is harvested.

COLLETOTRICHUM KAHAWAE: This fungus causes coffee berry disease. In 1869, it devastated so many coffee plantations in Ceylon (now Sri Lanka) that farmers switched to growing tea. Tea leaves were exported to Britain, creating a nation of tea lovers in the process!

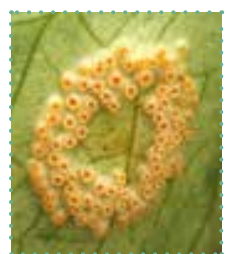

PUCCINIA FUNGAL RUST FAMILY: The individual species in this family specialise in causing diseases in specific cereals. For example, black stem rust disease on wheat is a major problem for agriculture, which in the 1950s completely destroyed the USA wheat crop for several years.

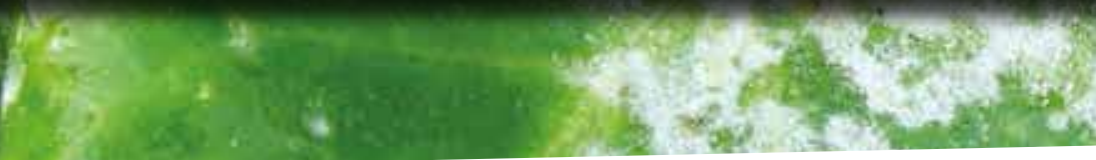

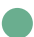 AND DR PAUL KERSEY} ASK DR KIM HAMMOND-KOSACK

HOW DID PHI-BASE AND PHYTOPATH BEGIN?

Kim: I wanted to discover how pathogens attack plants to cause disease. Between 1999 and 2002, with the help of Dr Martin Urban, I curated all the relevant published papers into an Excel table. We realised there wasn't a database available for the type of gene function we were interested in, so in 2003, the Excel sheet turned into the database called PHI-base.

Paul: PhytoPath came about because I was looking to connect Ensembl (a database I was already operating) to more functional data from pathogen species - and $\mathrm{PHI}$-base was an obvious partner.
WHAT WAS THE KEY DISCOVERY IN YOUR FIELD OF RESEARCH?

In the early 1980s in California (USA), Doug Dahlbeck, Noel Keen and Brian Staskawicz carried out a game-changing experiment concerning bacterial avirulence genes, which trigger disease resistance during infection of a specific host plant. They used a method called 'shotgun cloning' of the entire genome from one avirulent race of bacteria and transferred this in small fragments into a virulent race. When the correct DNA fragment was chosen this changed the virulent race to avirulent - one that didn't cause disease. By 1999, around 100 bacterial avirulence genes had been cloned and this data was curated into PHI-base.
WHAT'S NEXT FOR PHI-BASE AND PHYTOPATH

We've developed a tool, PHI-Canto, to enable scientists to enter new information directly into PHI-base. Now we need to make videos and publicise it! We also want to catalogue the pathogen target sites of all known anti-infective chemistries for fungicides, bactericides and antibiotics, alongside the variant mutant genes that lead to unwanted microbial resistance to these chemistries. 


\section{WHO'S WHO IN THE RESEARCH TEAM}

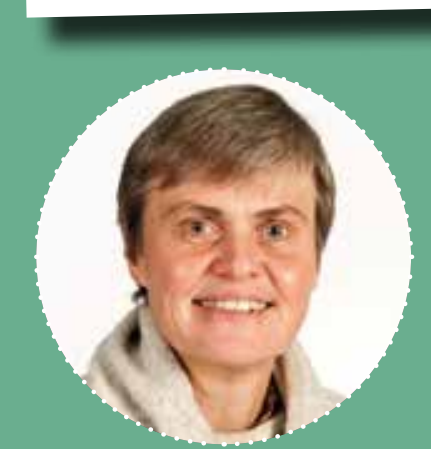

KIM HAMMONDKOSACK

Co-founder and team leader of PHI-base

Key skills: plant pathology,

molecular plant pathology, genetics and molecular genetics, bioinformatic analysis of pathogen genomes.

Nationality: British

Why I love my job: I want to improve the health of crops, humans, animals and natural ecosystems.

Fun fact: I love photographing the natural world.

Kim has more than 30 years' experience in molecular plant pathology and genetics, investigating the harmful fungi and viruses that infect various

food plants such as wheat, tomatoes and oilseed rape. Kim and her research team work at the cutting edge with these infectious organisms - combing through their newly decoded genomes (DNA blueprints), looking for any weakness in their defences. They then share this information online with scientists who are fighting to protect their own food supplies all over the world.

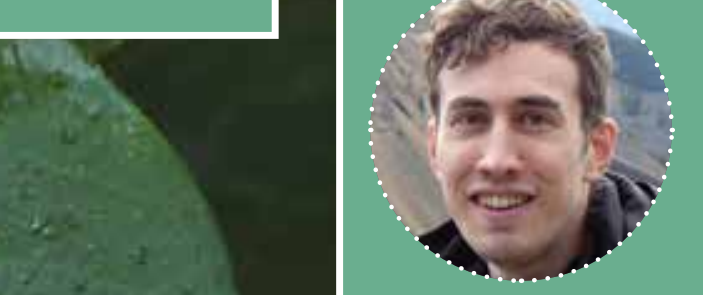

PAUL KERSEY

Investigator

Key skills: Bioinformatics

Nationality: British

Why I love my job: I'm interested in understanding the science, but it helps that the cause is so obviously important to mankind.

Fun fact: I was once deported from Russia.

$\begin{array}{lll} & \begin{array}{l}\text { MARTIN URBAN } \\ \vdots\end{array} & \begin{array}{l}\text { Co-founder of PHI-base } \\ \text { Key skills: Molecular plant pathology of fungal pathogens, computer sciences }\end{array} \\ \vdots & \begin{array}{l}\text { Nationality: German } \\ \text { Why I love my job: I'm fascinated by, and really enjoy, understanding how } \\ \text { microbial pathogens can infect plants and animals. } \\ \text { Fun fact: I love jazz! }\end{array}\end{array}$

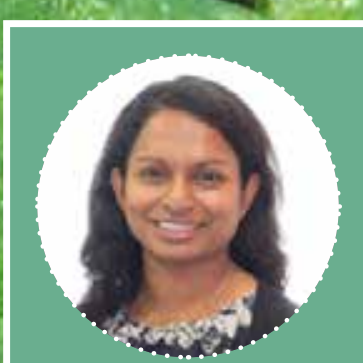

NISHADI DE SILVA

Project leader

Key skills: Bioinformatics, computer science, science communication

Nationality: British Sri Lankan

Why I love my job: The work I'm involved in is directly linked to improving health and welfare.

Fun fact: I love running!

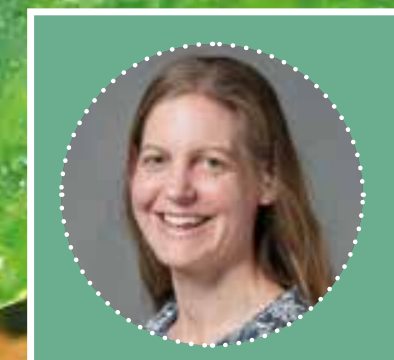

ALAYNE CUZICK

PHI-base biocurator

Key skills: Biocuration (organising biological data and making it accessible)

Nationality: British

Why I love my job: I have always been fascinated by nature - it's so essentia for the health of the planet.

Fun fact: I love plants - I always have at least 10 at home!
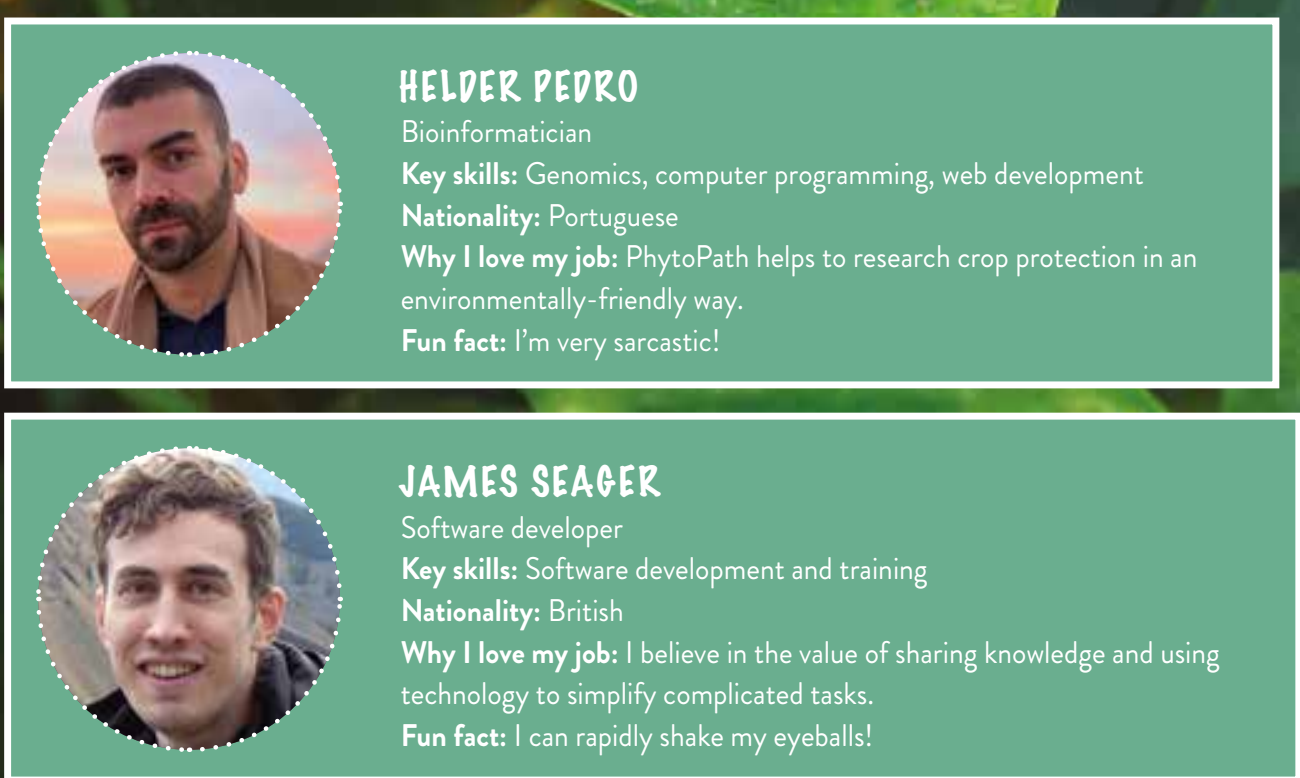

